\title{
Biomass Gasification: Documented Information for Adoption/Adaptation and Further Improvements toward Sustainable Utilisation of Renewable Natural Resources
}

\author{
Andrew Agbontalor Erakhrumen \\ Department of Forestry and Wildlife, University of Uyo, Uyo 520001, Nigeria \\ Correspondence should be addressed to Andrew Agbontalor Erakhrumen, erakhrumen@yahoo.com
}

Received 13 April 2012; Accepted 8 July 2012

Academic Editors: R. S. Adhikari and D. C. Martins

Copyright ( 2012 Andrew Agbontalor Erakhrumen. This is an open access article distributed under the Creative Commons Attribution License, which permits unrestricted use, distribution, and reproduction in any medium, provided the original work is properly cited.

In many developing countries, biomass use as a means of generating energy is still relevant with the developed countries also gradually increasing this source of energy in their energy-mix. Furthermore, increased research and developmental efforts concerning bioenergy are more in these developed countries compared to many of the developing ones. This might have contributed to the present level of biomass conversion technologies, most of which are observed to be outdated, in developing countries such as those in sub-Sahara Africa. Improving on the available old bioenergy conversion technologies may not only be adequate for sustainable utilisation of renewable natural resources; there may be the need for adoption/adaptation of other recent research outputs geared toward optimal resource utilisation in this regard. Contributing to and application of improvements in biomass conversion technologies, such as gasification techniques, might assist in achieving this aim. This article was therefore conceived at highlighting information concerning biomass gasification in such a way as to sensitise the different stakeholders in research and developmental issues in developing countries where there are still challenges facing this sector. The language and presentation of the article was aimed at specifics avoiding too many technical details for the benefit of experts and non-experts alike.

\section{Introduction}

History has it that the series of mankind's developmental stages, cultures, and technologies were strongly linked with energy and associated systems [1-3]. Right from when fire was accidentally "discovered" to the period of Industrial Revolution and the recent "jet age" including the present period of high-technological innovations/inventions, the fundamental driving force for these developments, apart from the human mind, has been the generation and use of energy in a continuously increasing manner, a development that has particularly accelerated upwards in intensity and scale approximately in the last two hundred years or thereabout, after the discovery and start of large-scale use of fossil-derived fuels [2].

Prior to the discovery of fossil-derived fuels such as coal, crude oil, and natural gas, the main source of energy was from biomass, most especially lignocellulosic materials $[1,3-5]$. However, the world is presently heavily reliant on fossil fuels, most especially crude oil and natural gas, as source of energy with the bulk of this usage being in the advanced/developed countries while the less advanced/developing countries still have most of their inhabitants largely dependent on biomass energy, particularly at household levels $[6,7]$, although, this is not to ignore the fact that many of these advanced/developed countries are gradually increasing bioenergy utilisation in their energy$\operatorname{mix}[3,7,8]$.

In addition, irrespective of the fact that the advanced countries are presently heavily reliant on fossil fuels, researchers in these countries are also optimising efforts in bioenergy-related researches (e.g., [2,9]), as biomass is estimated to be contributing in order of $10-14 \%$ of the world's power supply $[10,11]$, with a likelihood of an increase in this contribution in the near future. The increasing research in and utilisation of bioenergy is partly in preparation for future unpredictability in supply, demand, and price of fossil fuels and associated products as a result 
of current increasing usage of these types of fuels and their supposed expected future finiteness $[1,9,12]$.

Furthermore, these researches concerning the sustainable application of bioenergy are also increasing owing to the potential for carbon neutrality expected from bioenergy utilisation when issues concerning mitigation of the currently experienced global climate change are considered [13] as biomass, when grown and converted in a closedloop feedstock production scheme, is expected to claim a neutral position in the build-up of atmospheric greenhouse gases as the carbon dioxide generated during biomass combustion is absorbed by the new biomass being grown $[1,14]$. Thus, the observed persistence in the application of biomass, particularly lignocellulose, as energy source, calls for concerted efforts from stakeholders toward its sustainable sourcing for this purpose.

These efforts are expected in order not to underestimate the various types of influences and/or impacts of local peculiarities on this use $[3,6,7,15-20]$. However, sustainable sourcing of bioenergy may be hampered by poor/inefficient conversion of biomass to biofuel and bioenergy, most especially in the developing countries. These countries are still faced with challenges concerning the level and rate of technological advancement $[1,3]$ perhaps owing to the observed inadequate research capacities [21]. Thus, there is the need for continuous improvement in biofuel conversion methods/processes bearing in mind the likely usefulness of various developmental outcomes from studies and researches worldwide for the benefit of less technologically advanced countries [1].

This paper written in simple language and presented to highlight specifics is therefore focused on a brief overview of gasification technologies with particular emphasis on gasification of lignocellulosic materials. Gasification technology, whose advantage has been known for nearly two hundred years [22], is noted to be an attractive route for the production of fuel gases from biomass, as any biomass material can undergo gasification, in comparison to ethanol production or biogas where only selected biomass materials can produce the fuel [23]. In addition, this write-up is necessary because most of the equipment designed to burn oil or gas is not generally capable of directly burning solid lignocellulosic materials.

Furthermore, the use of producer gas to power diesel (dual-fuel) and petrol engines is an old technology that is continuously been improved upon. For instance, during World War II, there were close to 1 million engines running on producer gas all over the world [24] most of which were in occupied territories in Europe. However, the use of gas in small (3-5 kW) engines is of recent origin [25] because of increased small-scale power requirements in some developing countries. Apart from this, fuels are efficiently combusted at gaseous phase under proper condition coupled with the fact that the bulk of biomass used as fuel in developing countries is still comprised mainly of solid lignocellulosic materials $[3,4,6-8,26]$.

Improving the efficiency of use and wastage reduction as a result of using biofuel from lignocellulosic materials is, therefore, dependent on factors such as improvement/advancement in technology [1]. Therefore, current information regarding systems capable of converting biomass to combustible gas(es) is necessary while increasing research efforts toward systems compatible with current oil/gas-designed equipment. Documenting the advances in biomass gasification is expected to assist in stimulating necessary improvements in the different methods of biomass conversion to energy and its utilisation most especially in most developing countries where there are still challenges concerning level and rate of technological advancement.

\section{Brief Overview of Biomass Gasification Technologies and Types of Gasifiers}

Biomass, in the context of thispaper, is an organic material from recently living things, including plant matter from trees and other woody species, grasses, and agricultural crops. Biomass is composed primarily of carbon, oxygen, and moisture including impurities, such as sulphur, ash, among others. Green plants combine water and carbon dioxide to form sugar building blocks and oxygen gas as depicted in (1). The required energy for this process is obtained from light (sunlight in most cases) via photosynthesis that is facilitated by chlorophyll. These sugar building blocks are the starting point for the building up of plant biomass into which part of the absorbed energy is stored:

$$
n \cdot \mathrm{H}_{2} \mathrm{O}+n \cdot \mathrm{CO}_{2}+\text { Light } \stackrel{\text { Chlorophyll }}{\longrightarrow}\left(\mathrm{CH}_{2} \mathrm{O}\right)_{n}+n \cdot \mathrm{O}_{2}
$$

Biomass gasification is a type of thermochemical route resulting from the process of heating biomass, such as lignocellulosic materials in an oxygen-starved environment at elevated temperatures, $500-1400^{\circ} \mathrm{C}$, or at about 800 $1700 \mathrm{~K}$, and at atmospheric or elevated pressures up to 33 bar (480 psi) until volatile pyrolysis gases such as carbon monoxide, hydrogen, among others, are released from such biomass. The aim of gasification is the almost complete transformation of the constituents of biomass into gaseous form so that only the ashes and inert materials remain [27].

This type of gasification, under the described temperature and pressure condition, is the conversion of an organically derived, carbonaceous feedstock or solid biomass by partial oxidation into a gaseous product, synthesis gas, or "syngas," which stands for nitrogen-free gases from oxygen, steam or hydrogen gasification with negligible hydrocarbon content or combustible gas mixture normally called "producer gas," a nitrogen diluted gas mixture which mostly contains hydrocarbons obtained with air as gasification agent.

Gasification process involves conversion of biomass to combustible gas mixtures in the absence of air or with less air than the stoichiometric requirement of air for complete combustion. In a sense, gasification is a form of incomplete combustion; heat from solid biomass creates gases which are unable to burn completely, due to insufficient amounts of oxygen from the available supply of air [27].

The gaseous products of biomass gasification consist primarily of hydrogen $\left(\mathrm{H}_{2}\right)$ and carbon monoxide $(\mathrm{CO})$, 
with lesser amounts of carbon dioxide $\left(\mathrm{CO}_{2}\right)$, water $\left(\mathrm{H}_{2} \mathrm{O}\right)$, methane $\left(\mathrm{CH}_{4}\right)$, higher hydrocarbons $\left(\mathrm{C}_{x} \mathrm{H}_{y}\right)$, nitrogen $\left(\mathrm{N}_{2}\right)$, and particulates $[10,14]$ noting that the composition/quality of the producer gases varies widely with the properties of the biomass, employed gasification reactor type, the gasifying agent, and the operating conditions of the gasification process $[2,28]$.

Examples of treatment conditions that the quality of producer gas may depend on are temperature, pressure, hold time, heating rate (which is associated with the nature of biomass, particle size of the feed and temperature, etc.), pyrolysis atmosphere, among others [14]. The oxidant used, in the case where this is needed, can be air, pure oxygen, steam, or a mixture of these gases. Partial combustion produces $\mathrm{CO}$ as well as $\mathrm{H}_{2}$ which are both combustible gases. Air-based gasifiers typically produce a product gas containing a relatively high concentration of nitrogen with a low heating value when compared to oxygen and steambased gasifiers that produce a product gas containing a relatively higher concentration of hydrogen and $\mathrm{CO}$ with a higher heating value $[10,14]$.

The producer gas can be burned directly to produce heat or used as a fuel, after the removal of tar and particulates, to run internal combustion engines (both compression and spark ignition), for gas engines and gas turbines to generate electricity, and can be used as a substitute for furnace oil in direct heat applications. It can also be used as a feedstock (syngas) in the synthesis of chemicals such as methanol and fuel production $[2,9,14,23]$, although it is noteworthy at this stage that there is no standard gasifier that is able to handle a wide range of biomass types, as a result of nonhomogeneous character of most biomass resources, which pose difficulties in maintaining constant feed rates to gasification units; therefore, there is the need for proper equipment design for the gasification process.

In gasifying the different types of biomass, there will be the need for appropriate equipment designed for this purpose, as stated earlier. The equipment, a variety of which have been developed, collectively known as gasifiers, can be simply grouped into the following major classifications/differentiations [11, 14, 29-33] based on the means of supporting the biomass in the reactor vessel, the direction of flow of both the biomass and oxidant, and the way heat is supplied to the reactor $[10,14]$. These differentiations can be briefly categorised into fixed-bed (updraft and downdraft), fluidized-bed (bubbling and circulating), and entrained flow gasifiers (Figures 1, 2, 3, 4, and 5). The units can operate at atmospheric or higher pressure. The gasification medium is generally air (air-blown), oxygen (oxygen-blown), steam, or combinations of these [33].

2.1. Fixed-Bed Updraft or Counter Current Gasifier. This type of configuration is the oldest and simplest form of gasifier; it is still used for coal gasification [10] and is noted to have relatively low cost owing to the simple reactor concept. Biomass feedstock is introduced at the top of the reactor, and a grate at the bottom of the reactor supports the reacting bed. Air or oxygen and/or steam are introduced below and through the grate and diffuse up through the bed of biomass

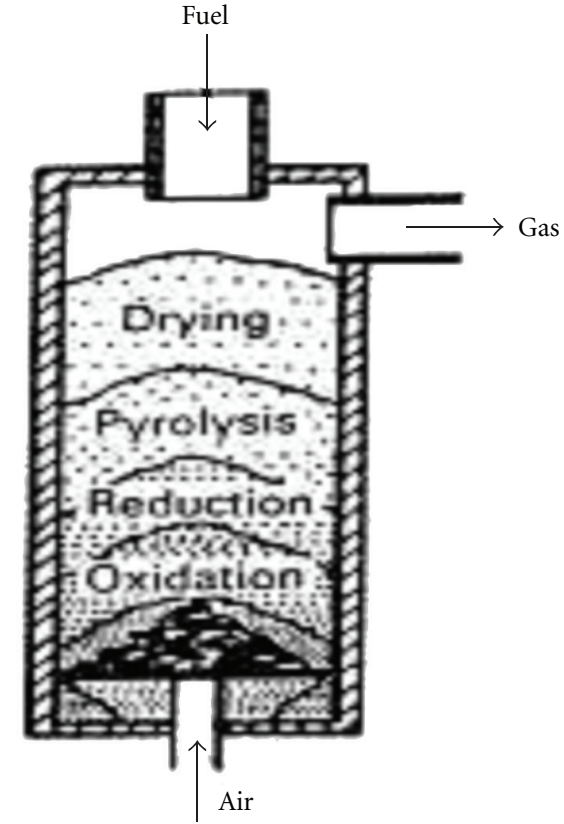

FIgURE 1: Schematic illustrative diagram of a fixed-bed updraft gasifier. Source: Warnecke [35].

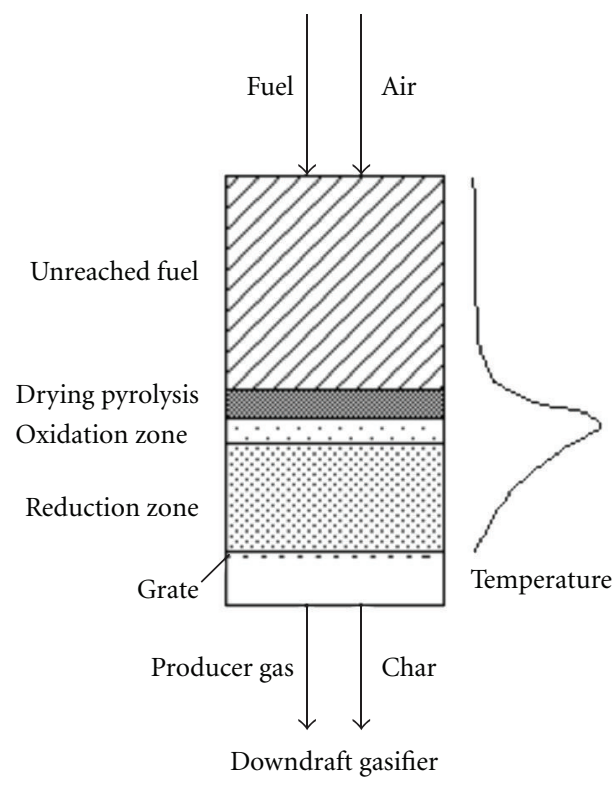

FIGURE 2: Schematic illustrative diagram of a fixed-bed downdraft gasifier. Source: Williams et al. [33].

and char. A complete combustion of char takes place at the bottom of the bed, liberating $\mathrm{CO}_{2}$ and $\mathrm{H}_{2} \mathrm{O}$. These hot gases $\left(\sim 1000^{\circ} \mathrm{C}\right)$ pass through the bed above, where they are reduced to $\mathrm{H}_{2}$ and $\mathrm{CO}$ and cooled to about $750^{\circ} \mathrm{C}$.

Continuing up the reactor, the reducing gases $\left(\mathrm{H}_{2}\right.$ and $\mathrm{CO})$ pyrolyse the descending dry biomass and finally dry the incoming wet biomass, leaving the reactor at a low temperature $\left(\sim 500^{\circ} \mathrm{C}\right)[10,29,30,34]$. The large internal drying zone allows the conversion of biomass with up to $50 \%$ humidity [2]. The producer gas is extracted at the top 


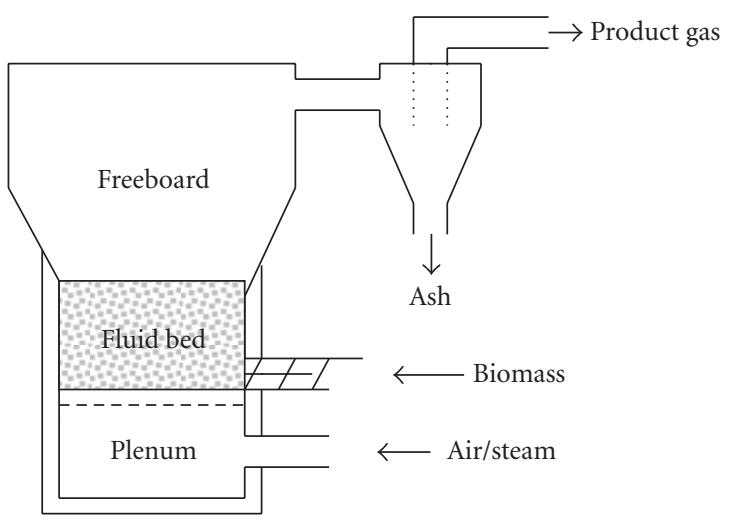

FIGURE 3: Schematic illustrative diagram of a bubbling fluidizedbed gasifier. Source: Williams et al. [33].

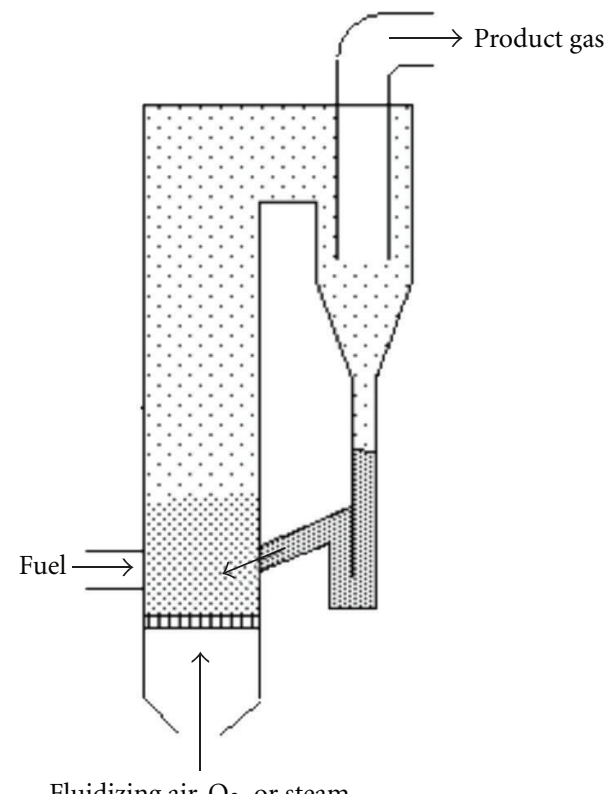

Fluidizing air, $\mathrm{O}_{2}$, or steam

FIGURE 4: Schematic illustrative diagram of a circulating fluidizedbed gasifier. Source: Williams et al. [33].

of the gasifier after passing through the biomass material present in the gasifier. Updraft gasification producer gases are relatively cold with outlet temperatures typically between 200 and $300^{\circ} \mathrm{C}$ [2]. Owing to the use of air as gasification agent, the heating value of updraft gasification producer gases is low while the tar loads may be very high as tars formed in the devolatilization zone only pass the colder drying zone before exiting the updraft gasifier with cracking not likely to occur.

2.2. Fixed-Bed Downdraft or Cocurrent Gasifier. This type of gasifier, which is the second common type of fixed bed reactors, has the same mechanical configuration as the updraft gasifier except that the oxidant and product gases flow down the reactor, in the same direction as the biomass feedstock with the producer gas exiting the gasifier at the bottom. In contrast to the updraft gasification, the heat

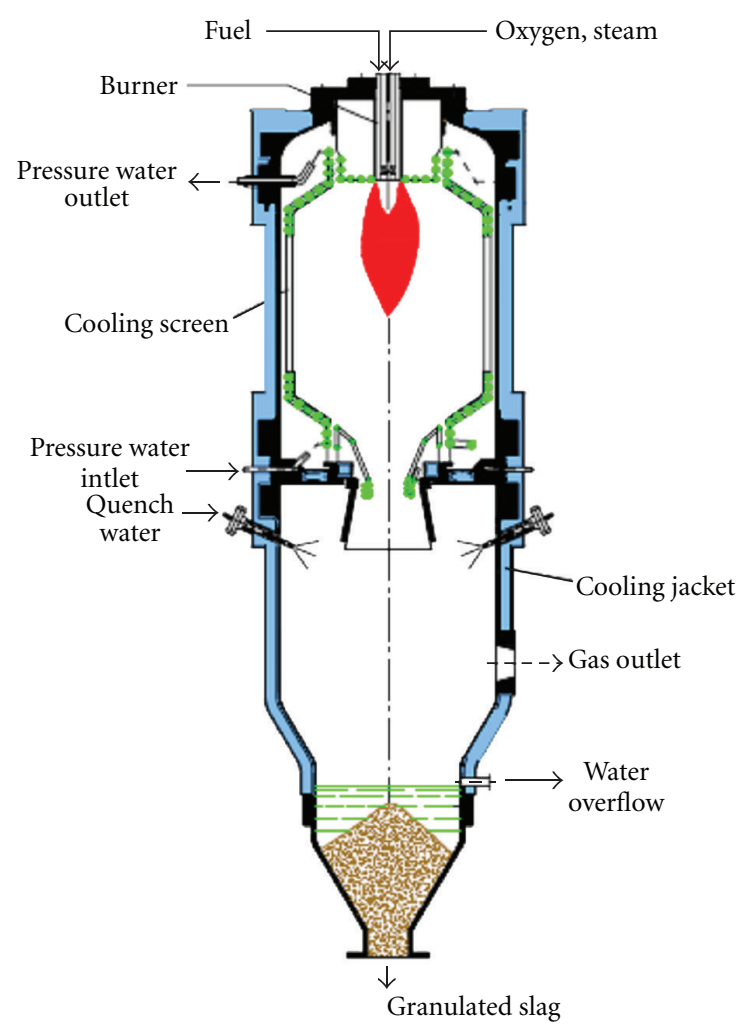

FIGURE 5: Schematic illustrative diagram of an entrained flow gasifier. Source: Williams et al. [33].

required to dry and decompose biomass feedstock does not directly come from the producer gas but is introduced to these zones via gasification air preheating and/or heating of the reactor walls. This gasification process can combust up to $99.9 \%$ of the tars formed.

Low moisture biomass $(<20 \%)$ and air or oxygen are ignited in the reaction zone at the top of the reactor. The flame generates pyrolysis gas/vapour, which burns intensely leaving 5 to $15 \%$ char and hot combustion gas. These gases flow downward and react with the char at 800 to $1200^{\circ} \mathrm{C}$, generating more $\mathrm{CO}$ and $\mathrm{H}_{2}$ while being cooled to below $800^{\circ} \mathrm{C}$. Similar to the updraft gasification, the heating value of downdraft producer gases is low, however, with a low tar loads, resulting from the reactor internal tar cracking. Finally, unconverted char and ash pass through the bottom of the grate and are sent to disposal $[2,10,29,30]$.

The updraft and downdraft gasifiers are usually small batch operated devices in which the fuel bed is held stationary while the reaction front passes through it, or the bed can move through reaction or mechanical displacement. Often, they are suction-type gasifiers attached to an engine. These gasifier types would not likely be the preferred choice for hydrogen or liquid fuels production from biomass, although parallel trains of such gasifiers have been used with coal for this purpose [33].

2.2.1. Fluidized-Bed Gasifiers. Fluidized-bed gasifiers are categorised based on their fluid dynamics and heat transfer. 
Generally, the biomass is introduced near the bottom of the gasifier where it is immediately mixed with a bed material such as sand. The portion of bed material in the reactor volume is typically over $90 \%$ [36]. The gasification agent is usually introduced through a nozzle floor or a frit. Owing to the mixing of the biomass feedstock with the bed material, the subprocesses of gasification do not take place in a defined zone of the reactor but throughout the whole reactor volume, which yields almost isothermal conditions. The temperature in the gasification reactors is usually kept below $950^{\circ} \mathrm{C}$ to prevent slagging of the bed material [36]. The producer gas is extracted via a cyclone at the top of the gasifier.

2.3. Bubbling Fluidized-Bed. A bubbling fluidized bed consists of fine, inert particles of sand or alumina, which have been selected for size, density, and thermal characteristics. As gas (oxygen, air or steam) is forced through the inert particles, a point is reached when the frictional force between the particles and the gas counterbalances the weight of the solids. At this gas velocity (minimum fluidization), bubbling and channeling of gas through the media occur, such that the particles remain in the reactor and appear to be in a "boiling state." The fluidized particles tend to break up the biomass fed to the bed and ensure good heat transfer throughout the reactor $[10]$.

2.4. Circulating Fluidized Bed. Circulating fluidized bed gasifiers operate at gas velocities higher than the minimum fluidization point, resulting in entrainment of the particles in the gas stream. The entrained particles in the gas exit the top of the reactor, are separated in a cyclone, and returned to the reactor [10]. This type of gasifier offers higher conversion rates and efficiencies. The bed material flows up with the fluidizing gas and is carried over into a cyclone that separates most of the particles from the gas stream, which are reinjected (recirculate) into the lower part of the bed. Ideally, the fuel particles are small enough to completely react before carried over into the cyclone, but in practice large fuel particles recirculate with bed media until small and light enough to be carried out with the product gas exiting the cyclone or other separation device [33].

2.5. Entrained Flow. These types of gasifiers are used extensively to convert petroleum residues (e.g., petroleum coke) to useful products and energy. Most coal gasification is done with entrained flow systems. Entrained flow gasifiers have high gas velocities and high material throughput. Consequently, time for reaction (residence time), is short which requires the feedstock to be of very small particle size, a liquid or liquid slurry. The systems are generally oxygen blown and can be pressurised or atmospheric. High temperature $\left(>1250^{\circ} \mathrm{C}\right)$ is generated from combustion in oxygen which melts the ash (sometimes called slagging gasifier) and requires reactor cooling. Little to no tar is formed as the feedstock is essentially completely converted to $\mathrm{H}_{2}, \mathrm{CO}, \mathrm{CO}_{2}$, and $\mathrm{H}_{2} \mathrm{O}[33]$.

\section{Simplified Process Flow during Gasification}

Studies have shown that the chemistry of biomass gasification, just like that for combustion, is complex and variable, although the same chemical laws which govern combustion processes also apply to gasification [27]. However, this type of gasification can be simply described to proceed primarily via a two-step process, that is, pyrolysis followed by gasification as simply depicted in Figure 6.

Basically, irrespective of the type of gasifier, the processes occurring in any gasifier include drying, pyrolysis, reduction, and oxidation, noting that these processes may occur simultaneously or sequentially depending on the reactor design. Pyrolysis is the decomposition of the dried biomass feedstock by heat. This step, also known as devolatilisation, is endothermic and produces 75 to $90 \%$ volatile materials in the form of gaseous and liquid hydrocarbons. During pyrolysis, thermally unstable components such as lignine in biomass are broken down and evaporate with other volatile components.

In satisfying the requirements of the endothermic reactions, heat may be supplied directly or indirectly to the biomass feedstock. The gasification is autothermal if the required heat is produced via partial combustion of the feed within the same reactor or allothermal if the heat is produced in a spatially separated second reactor and introduced to the gasification reactor by means of a bed material, heat pipes, among others [2].

The hydrocarbon fraction may consist of methane, polycyclic aromatic hydrocarbons (PAH), and tar mix consisting of oxygenated species such as phenols and acids as well as light aromatics, heavy tars $\left(\mathrm{C}_{1}-\mathrm{C}_{36}\right.$ components), for example, pyrene and anthracene. The tar formed during pyrolysis can be sticky like asphalt and is known to be highly carcinogenic and represent a great challenge to machinery when the producer gas is transported, stored, and used. Reducing the production of tar and particulates in the gasification demands a thorough knowledge of the chemical kinetics of the gasification process.

The composition of the products of pyrolysis can be influenced by many parameters, such as particle size of the biomass, temperature, pressure, heating rate, residence time, and catalysts [28]. The remaining nonvolatile material that contains high carbon content is referred to as char [29]. The major unbalanced chemical reaction is depicted in (2):

$$
\begin{gathered}
\text { Biomass } \stackrel{\text { heat }}{\longrightarrow} \mathrm{C}_{x} \mathrm{H}_{y}+\mathrm{C}_{x} \mathrm{H}_{y} \mathrm{O}_{z}+\mathrm{H}_{2} \mathrm{O}+\mathrm{CO}_{2}+\mathrm{CO} \\
+\mathrm{H}_{2}+\text { and so forth }
\end{gathered}
$$

The volatile hydrocarbons and char are subsequently converted to syngas or producer gas in the second step that is, gasification [10]. Depending on the nature of the raw solid feedstock and the process conditions, the char formed from pyrolysis contains $20-60 \%$ of the energy input [37]. Therefore, the gasification of char is an important step for the complete conversion of the solid biomass into gaseous products and for an efficient utilisation of the energy in the biomass [14]. 


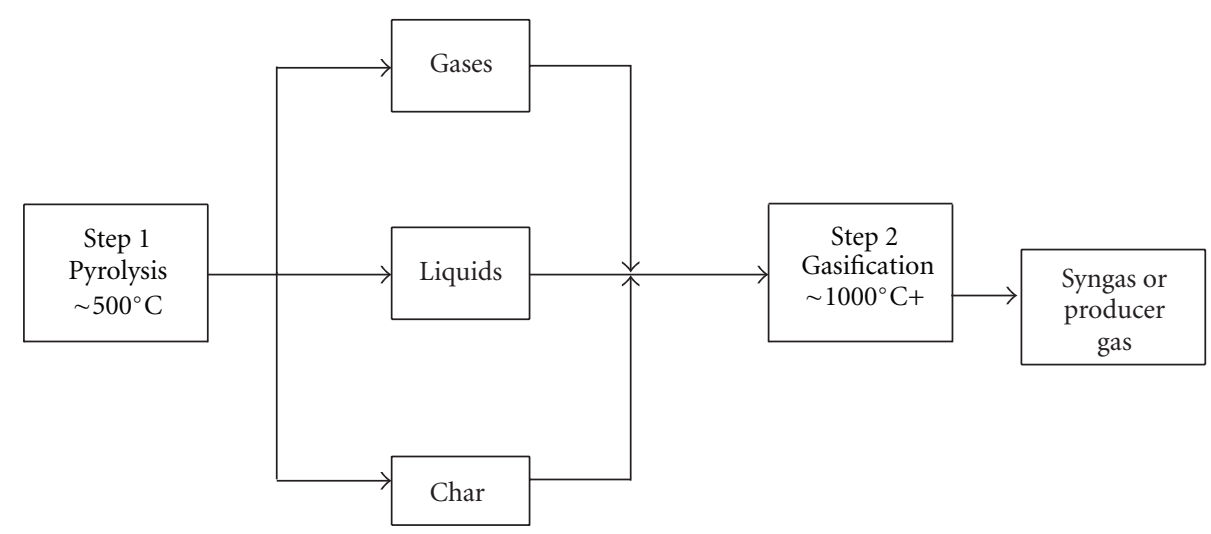

FIgURE 6: Basic steps in biomass gasification. Source: Adapted from Ciferno and Marano [10].

In addition, the efficiency of a gasification process is given by the cold gas efficiency, which relates the chemical energy content of the produced gas to that of the biomass before conversion [2]. Depending on the process conditions, the cold gas efficiencies of today's biomass gasification processes range from 50 to over $90 \%$ [36]. A few of the major reactions involved during pyrolysis and gasification are listed as (3) to (9) $[29,30]$.

\section{Exothermic Reactions}

Combustion

$$
\text { (biomass volatiles/char) }+\mathrm{O}_{2} \longrightarrow \mathrm{CO}_{2}
$$

Partial Oxidation

$$
\text { (biomass volatiles/char) }+\mathrm{O}_{2} \longrightarrow \mathrm{CO}
$$

Methanation

$$
\text { (biomass volatiles/char) }+\mathrm{H}_{2} \longrightarrow \mathrm{CH}_{4}
$$

Water-Gas Shift

$$
\mathrm{CO}+\mathrm{H}_{2} \mathrm{O} \longrightarrow \mathrm{CO}_{2}+\mathrm{H}_{2}
$$

CO Methanation

$$
\mathrm{CO}+3 \mathrm{H}_{2} \longrightarrow \mathrm{CH}_{4}+\mathrm{H}_{2} \mathrm{O}
$$

\section{Endothermic Reactions}

Steam-Carbon reaction

$$
\text { (biomassvolatiles/char) }+\mathrm{H}_{2} \mathrm{O} \longrightarrow \mathrm{CO}+\mathrm{H}_{2}
$$

Boudouard reaction

$$
(\text { biomassvolatiles/char })+\mathrm{CO}_{2} \longrightarrow 2 \mathrm{CO}
$$

\section{Some Challenges Limiting the Benefits from Gasification Technologies}

Gasification technologies are increasingly seen as viable means of converting series of biomass feedstock into combustible gases that can be utilised in clean ways most especially in the developing countries where bioenergy is still very important, particularly at domestic/household level. However, gasifiers require high temperatures and heat transfer into cold biomass, thus, making them small is difficult. This is a challenge to making biomass gasification suitable for domestic cooking. In addition, there presently exists no standard gasifier that can be used to gasify a wide range of biomass types. This can be a challenge if and when biomass feedstock for a particular gasifier is either scarce or unavailable to users.

Furthermore, the variable tar load formed during pyrolysis stage of gasification of biomass feedstock is known to be highly carcinogenic and can reduce the efficiency of machinery parts, thereby, requiring special efforts toward reducing its quantity. This will particularly be an added burden on the user of such gasifier configuration. There is also the need for adequate ventilation for the gasification unit. In addition, there is the challenge of gaining control over the pyrolysis, gasification, and combustion in a small enough space to be used by individual households even as commercially available models of gasifiers are still scarce in the market in this part of the world.

\section{Concluding Remarks}

The application of biomass in generating energy has not been outmoded in those parts of the world that are still considered to be less advanced or developing. In similar manner, this application is also being intensified in the advanced/developed countries, and this usage in both climes has been observed to be increasing both in quantity and intensity. This, therefore, means that sustainable strategies for sourcing biomass for this purpose should be put in place. Efforts toward this may not be enough as underutilisation of and/or poor conversion technologies for biomass to energy, as presently experienced in many developing regions, like sub-Sahara Africa, may negatively affect sustainability of resource sourcing.

Improving the available technologies for converting biomass to energy and developing new ones that are in tandem with reality are expected to assist in this regard. For instance, biomass gasification has long been known to be a 
useful technology in converting different types of biomass feedstock into gaseous products, which can be combusted to generate energy or used in the synthesis of chemicals. However, as old as this technology is, it does not presently appear to be popular in many developing countries when compared to direct burning of solid biomass using inefficient devises that are characterised by unnecessary leakage of energy and subsequent wastage of biofuel.

It is, however, expected that if the abundance of documented information concerning biomass gasification is exploited in this part of the world, more biomass feedstock are likely to be efficiently used for generating energy and this will also very much likely reduce the pressure on the resource base. As also highlighted in this paper, biomass gasification technologies also require improvement efforts in order to maximise benefits from the available ones and also to develop new ones compatible with the different biomass feedstock and climes. The available technologies, particularly the recently improved versions, documented in the literature may serve as a good starting point in achieving these aims.

\section{References}

[1] A. A. Erakhrumen, "Overview of various biomass energy conversion routes," American-Eurasian Journal of Agricultural \& Environmental Sciences, vol. 2, no. 6, pp. 662-671, 2007.

[2] F. P. Nagel, Electricity from wood through the combination of gasification and solid oxide fuel cells: systems analysis and proof-of-concept [degree of doctor of sciences], A dissertation submitted to Swiss Federal Institute of Technology (ETHZ), Zurich, Switzerland, 2008.

[3] A. A. Erakhrumen, "Global increase in the consumption of lignocellulosic biomass as energy source: necessity for sustained optimisation of agroforestry technologies," ISRN Renewable Energy, vol. 2011, Article ID 704573, 8 pages, 2011.

[4] A. A. Erakhrumen, "Wood biomass as a major source of energy in sub-Sahara African region: implications for sustained research and education in agroforestry technologies," in In Research For Development in Forestry, Forest Products and Natural Resources Management, J. C. Onyekwelu, V. A. J. Adekunle, and D. O. Oke, Eds., Proceedings of the 1st National Conference of the Forests and Forest Products Society of Nigeria, pp. 205-211, Federal University of Technology, Akure, Nigeria, 2008.

[5] C. May-Tobin, "Wood for fuel," in The Root of the Problem: What'S Driving Tropical DeforeStation Today? p. 11, The Union of Concerned Scientist, 2011.

[6] A. A. Erakhrumen, "Energy value as a factor of agroforestry wood species selectivity in Akinyele and Ido local government areas of Oyo State, Nigeria," Biomass and Bioenergy, vol. 33, no. 10 , pp. 1428-1434, 2009.

[7] A. A. Erakhrumen, "Estimating the extent of influence of two intrinsic fuelwood properties on acceptance/retention of some woody species in agroforestry practices in Southwest Nigeria," Drvna Industrija, vol. 60, no. 4, pp. 209-218, 2009.

[8] A. A. Erakhrumen, "Recent trends in global and regional forest cover changes: continuously increasing forest size and quality are crucial steps toward environmental sustainability," in Proceedings of the 34th Annual Conference of the Forestry Association of Nigeria on Forestry in the Context of the Millennium Development Goals, L. Popoola, K. Ogunsanwo, and F. Idumah, Eds., pp. 476-496, Osogbo, Nigeria, December 2011.

[9] S. D. Phillips, J. K. Tarud, M. J. Biddy, and A. Dutta, "Gasoline from wood via integrated gasification, synthesis, and methanol-to-gasoline technologies," Tech. Rep. NREL/TP5100-47594, 2011, prepared for the National Renewable Energy Laboratory (NREL) under Contract Number DEAC36-08GO28308.

[10] J. P. Ciferno and J. J. Marano, "Benchmarking biomass gasification technologies for fuels, chemicals and hydrogen production," A Report Prepared For U.S. Department of Energy National Energy Technology Laboratory, 2002.

[11] P. McKendry, "Energy production from biomass-part 1: overview of biomass," Bioresource Technology, vol. 83, no. 1, pp. 37-46, 2002.

[12] A. A. Erakhrumen, "Implications of global economic recession/volatility in petroleum products' price, demand, and supply on fuelwood consumption and mangrove forests' survival in the Niger-Delta region," in Proceedings of the 33rd Annual Conference of the Forestry Association of Nigeria on the Global Economic Crisis and Sustainable Renewable Natural Resources Management, L. Popoola, F. O. Idumah, V. A. J. Adekunle, and I. O. Azeez, Eds., vol. 2, pp. 136-147, BeninCity, Nigeria, October 2010.

[13] T. Gumartini, "Biomass energy in the Asia-Pacific region: current status, trends and future setting," in Asia-Pacific Forestry Sector Outlook Study II, Food and Agriculture Organization of the United Nations Regional Office for Asia and the Pacific, 2009, Working Paper Series, Working Paper No. APFSOS II/WP/2009/26.

[14] J. Guo, Pyrolysis of Wood Powder and Gasification of WoodDerived Char, A Published Version of a Thesis Submitted to Technische Universiteit Eindhoven, 2004.

[15] A. A. Erakhrumen and O. Y. Ogunsanwo, "Women as major stakeholders in sustainable agroforestry fuelwood development," in Sustainable Forest Management in Nigeria: Lessons and Prospects. Proceedings of the 30th Annual Conference of the Forestry Association of Nigeria, L. Popoola, P. Mfon, and P. I. Oni, Eds., pp. 631-639, Kaduna, Nigeria, November 2005.

[16] O. Y. Ogunsanwo and A. A. Erakhrumen, "Gender influence on firewood sourcing for income generation in selected rural communities of Oyo State, Nigeria," Journal of Tropical Forest Resources, vol. 22, no. 1, pp. 76-83, 2006.

[17] O. Y. Ogunsanwo, A. A. Erakhrumen, and A. Otorokpo, "Energy value of selected parts of Peltophorum pterocarpum (D.C.) Backer ex K. Heyne: an avenue tree in the University of Ibadan Campus, Ibadan, Nigeria," OBECHE, vol. 26, no. 1, pp. 78-85, 2008.

[18] A. A. Erakhrumen, "Influence of specific gravity on wood species selection for agroforestry in some Local Government Areas of Oyo State, Nigeria," African Journal of Agricultural Research, vol. 3, no. 2, pp. 134-139, 2008.

[19] A. A. Erakhrumen, "Some other uses of accepted agroforestry fuelwood species based on traditional knowledge in selected rural communities of Oyo State, Southwest, Nigeria," in Proceedings of the International Conference in Traditional Forest-Related Knowledge and Sustainable Forest Management in Africa, J. A. Parrotta, A. Oteng-Yeboah, and J. Cobbinah, Eds., vol. 23 of IUFRO World Series, pp. 85-92, Accra, Ghana, 2009.

[20] A. A. Erakhrumen, O. Y. Ogunsanwo, and O. I. Ajewole, "Assessment of some other traditional uses of accepted agroforestry fuelwood species in akinyele and ido local government 
areas, Oyo State, Nigeria," International Journal of Social Forestry, vol. 3, no. 1, pp. 49-65, 2010.

[21] A. A. Erakhrumen, "State of forestry research and education in Nigeria and sub-saharan Africa: implications for sustained capacity building and renewable natural resources development," Journal of Sustainable Development in Africa, vol. 9, no. 4, pp. 133-151, 2007.

[22] C. Roth, Micro-Gasification: Cooking with Gas From Biomass: An Introduction to the Concept and the Applications of WoodGas Burning Technologies for Cooking, GIZ HERA-PovertyOriented Basic Energy Service, 1st edition, 2011.

[23] T. B. Reed M, Graboski, and M. Markson, "The SERI high pressure oxygen gasifier," Tech. Rep. SERI/TP-234-1455R, Solar Energy Research Institute, Golden, Colo, USA, 1982.

[24] A. K. Rajvanshi, "Biomass gasification," in In Alternative Energy In Agriculture-II, Y. Goswami, Ed., pp. 83-102, CRC Press, Boca Raton, Fla, USA, 1987.

[25] A. K. Rajvanshi and M. S. Joshi, "Development and operational experience with topless wood gasifier running a 3.75 kW diesel engine pumpset," Biomass, vol. 19, no. 1-2, pp. $47-$ 56, 1989.

[26] A. A. Erakhrumen, "Predicting net calorific value from specific gravity of fuelwood species from agroforestry plots in Southwestern Nigeria," The Nigerian Journal of Forestry, vol. 36, no. 1, pp. 61-70, 2006.

[27] H. LaFontaine and F. P. Zimmerman, "Construction of a simplified wood gas generator for fueling internal combustion engines in a petroleum emergency," Final Report, Federal Emergency Management Agency (FEMA), Washington, DC, USA, 1989, 20492 under FEMA Interagency Agreement Number: EMW-84-E-1737.

[28] J. J. Hos and M. J. Groeneveld, Biomass Gasification, John Wiley \& Sons, 1987.

[29] A. V. Bridgwater and G. D. Evans, "An assessment of thermochemical conversion systems for processing biomass and refuse," Tech. Rep. ETSU B/T1/00207/REP, Energy Technology Support Unit (ETSU) on behalf of the Department of Trade, 1993.

[30] T. B. Reed and G. Siddhartha, A Survey of Biomass Gasification 2001-Gasifier Projects and Manufacturers around the World, The National Renewable Energy Laboratory and the Biomass Energy Foundation, 2nd edition, 2001.

[31] D. J. Stevens, "Hot gas conditioning: recent progress with larger-scale biomass gasification systems: update and summary of recent progress," Tech. Rep. NREL/SR-510-29952, 2001.

[32] P. McKendry, "Energy production from biomass-part 3: gasification technologies," Bioresource Technology, vol. 83, no. 1, pp. 55-63, 2002.

[33] R. Williams, N. Parker, C. Yang, J. Ogden, and B. Jenkins, $\mathrm{H}_{2}$ Production Via Biomass Gasification: Advanced Energy Pathways (AEP) Project. Task 4. 1 Technology Assessments of Vehicle Fuels and Technologies, Public Interest Energy Research (PIER) Program, California Energy Commission. Prepared by UC Davis, Institute of Transportation Studies (ITS-Davis) One Shields Ave, Davis, Calif, USA, 2007.

[34] J. B. Kitto and S. C. Stultz, Steam Its Generation and Use, The Babcock \& Wilcox Company, Barberton, Ohio, USA, 40th edition, 1992.

[35] R. Warnecke, "Gasification of biomass: comparison of fixed bed and fluidized bed gasifier," Biomass and Bioenergy, vol. 18, no. 6, pp. 489-497, 2000.
[36] A. Vogel, M. Bolhàr-Nordenkampf, M. Kaltschmitt et al., Analyse und Evaluierung der Thermo-Chemischen Vergasung von Biomasse, Landwirtschafts $\mathrm{GmbH}$, Münster, Germany, 2006.

[37] G. Chen, The reactivity of char from rapid heating process under pressure: the role of the time-temperature-environment history of its formation [Ph.D. thesis], Royal Institute of Technology, Stockholm, Sweden, 1998. 

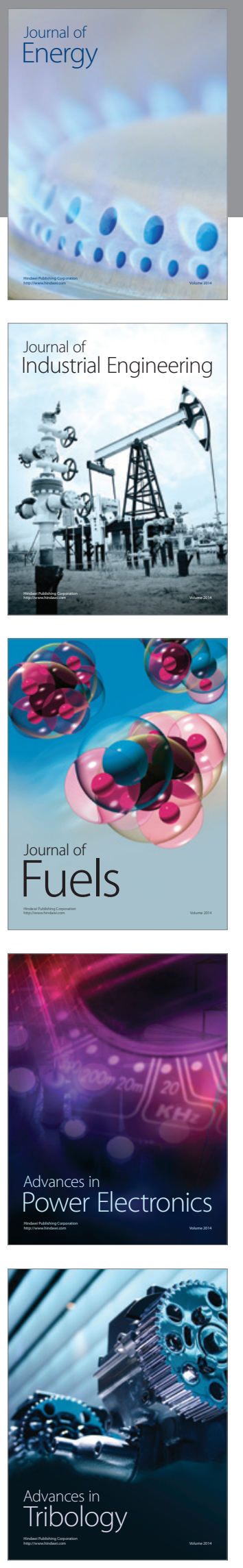
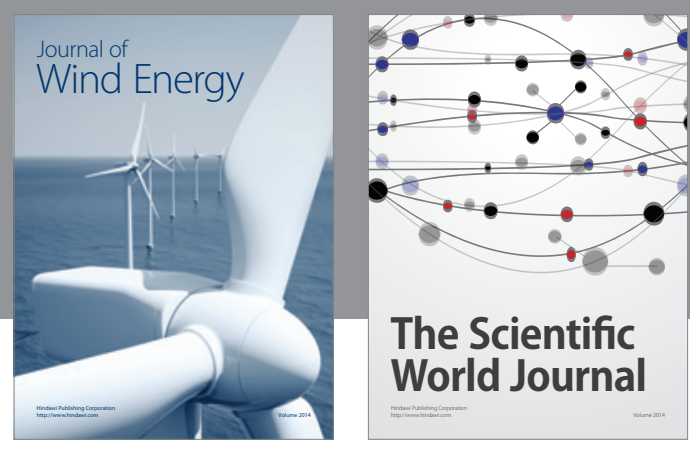

The Scientific World Journal

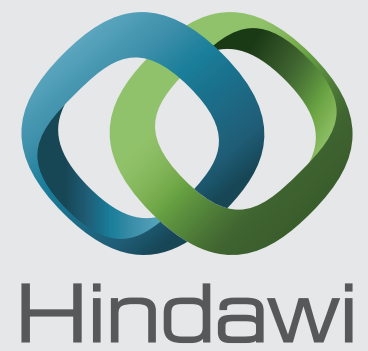

Submit your manuscripts at http://www.hindawi.com
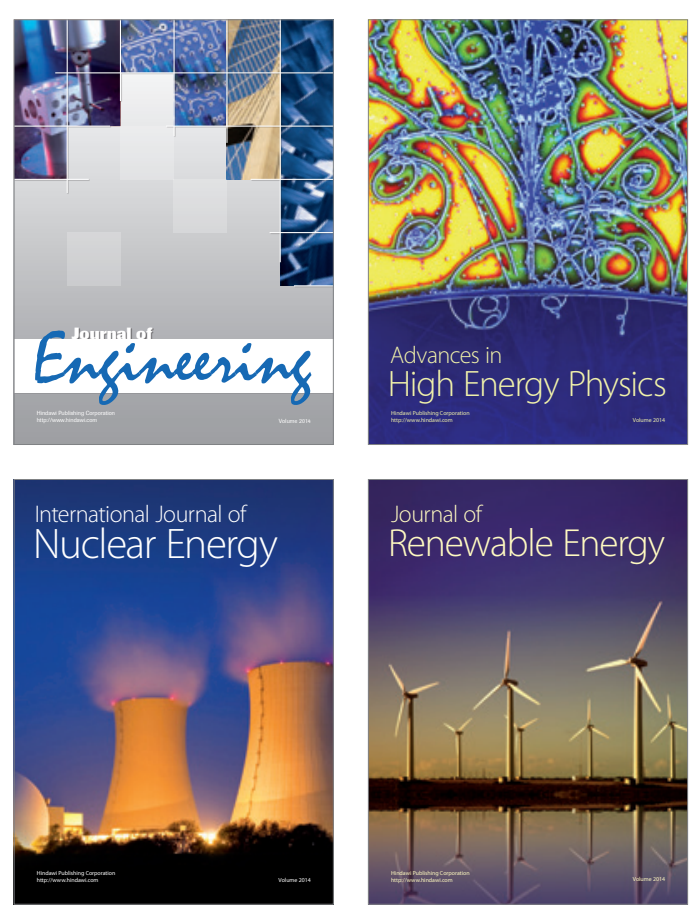

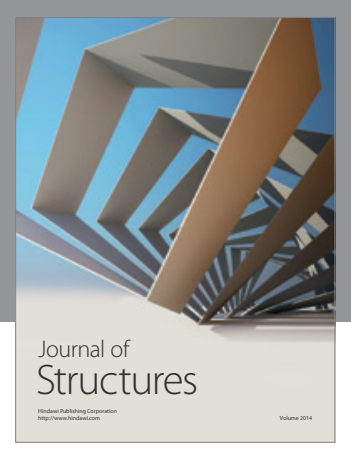

Rotating
Mechinery
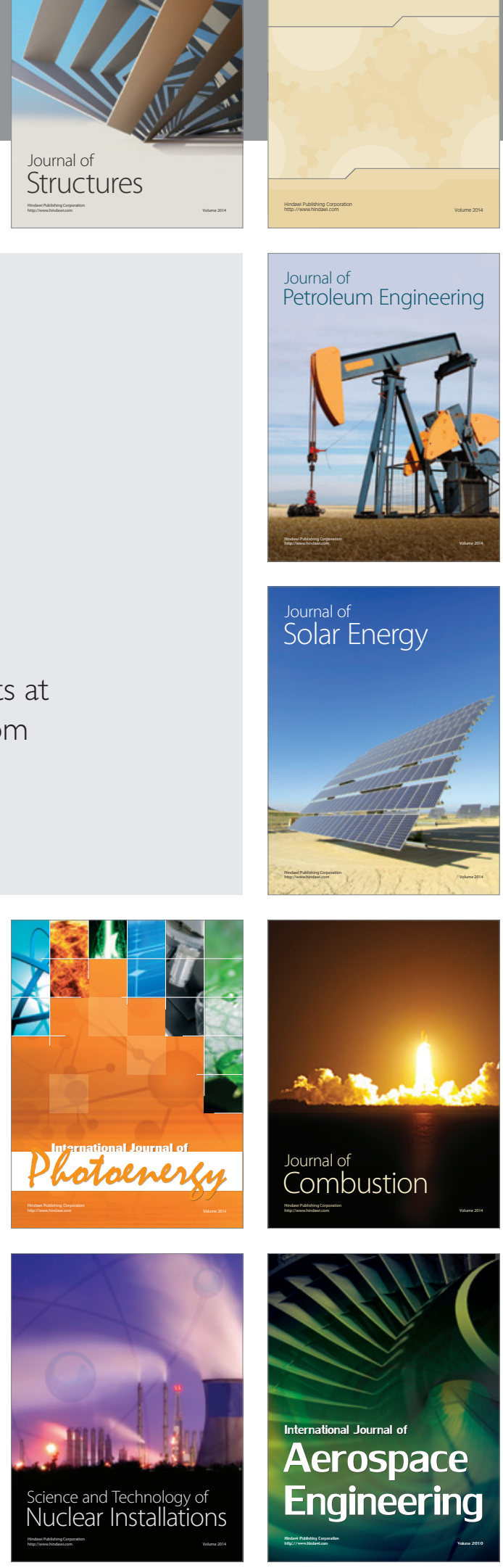